\title{
ANALISIS PELAYANAN KEPERAWATAN TERHADAP KEPUASAN PASIEN RAWAT INAP DI RSUD ARGAMAKMUR KABUPATEN BENGKULU UTARA
}

\section{Analysis Of Nursing Services Toward Satisfaction Of Investment Patients In Argamakmur Hospital North Bengkulu District}

\author{
Dwi Hermawati ${ }^{1}$, Milono ${ }^{2}$, Rahmi Armayana ${ }^{3}$ \\ ${ }^{1,2,3}$ Universitas Ratu samban Bengkulu \\ hermawatidwi284@gmail.com
}

\begin{abstract}
Abstrak
Pelayanan kesehatan seperti pelayanan keperawatan yang baik merupakan hal yang sangat dibutuhkan oleh masyarakat seperti peningkatan pelayanan yang diberikan Perawat maupun Dokter terhadap Pasien, peningkatan jumlah perawat dan dokter serta peningkatan manajemen pelayanan di Rumah Sakit sehingga pelayanan keperawatan terhadap masyarakat bisa berjalan maksimal dan kepercayaan masyarakat terhadap pelayanan kesehatan meningkat. Perubahan-perubahan dan perbaikan dalam manajemen pelayanan kesehatan khususnya di rumah sakit harus ditingkatkan mengingat banyaknya keluhan masyarakat mengenai pelayanan kesehatan khususnya pelayanan keperawatan. Setelah dianalisis dengan menggunakan bantuan komputerisasi di dapat $\mathrm{X}^{2}$ hitung sebesar 10, 544, apabila divabdingkan dengan Xtabel yaitu 3,84 dengan $\alpha=0,05$ dan $\mathrm{P}=0,001$ maka $X^{2}$ Hitung lebih besar dari Xtabel. Artinya bahwa terdapat hubungan yang signifikan antara Pelayanan keperawatan terhadap kepuasan pasien di ruang rawat inap. Dari hasil perhitungan selanjutnya diperoleh koefisien kontingensi (C) untuk analisis hubungan pelayanan keperawatan terhadap kepuasan pasien yaitu sebesar 0,569. Koefisien kontingensi maksimal (Cmkas) berdasarkan table $\mathrm{m}=2$ adalah sebesar 0,707, apabila dibandingkan dengan Chitung maka Cmaks lebih besar dari $\mathrm{C}$ hitung yang artinya terdapat hubungan yang nyata antara pelayanan keperawatan terhadap kepuasan pasien di ruang rawat inap RSUD Arga Makmur.
\end{abstract}

Kata Kunci : pelayanan keperawatan dan kepuasan pasien rawat inap

\begin{abstract}
Health services such as good nursing services are very much needed by the community such as improving services provided by nurses and doctors to patients, increasing the number of nurses and doctors and improving service management in hospitals so that nursing services to the community can run optimally and public trust in services health increases. Changes and improvements in the management of health services, especially in hospitals, must be improved given the large number of public complaints regarding health services, especially nursing services. After being analyzed using computerized assistance, X can be calculated at 10, 544, if it is compared with Xtable, which is 3.84 with $\alpha=0.05$ and $P=0.001$ then $X^{2}$ Count is greater than $X$ table. This means that there is a significant relationship between nursing services to patient satisfaction in the inpatient room. From the results of the calculation, the contingency coefficient $(C)$ is obtained for analysis of the relationship between nursing services to patient satisfaction, which is 0.569. Maximum contingency coefficient (Cmkas) based on table $m=2$ is equal to 0.707, when compared to Chitung, C maks is greater than Chitung, which means there is a significant relationship between nursing services to patient satisfaction in the inpatient ward of Arga Makmur Hospital.
\end{abstract}

Keywords: nursing services and inpatient satisfaction

Vol. 1, No. 1, Juni $2018: 37-41$ 


\section{PEDAHULUAN}

Pelayanan kesehatan seperti merupakan hal yang sangat dibutuhkan oleh masyarakat seperti peningkatan pelayanan yang diberikan Perawat maupun Dokter terhadap Pasien, peningkatan jumlah perawat dan dokter serta peningkatan manajemen pelayanan di Rumah Sakit sehingga pelayanan keperawatan terhadap masyarakat bisa berjalan maksimal dan kepercayaan masyarakat terhadap pelayanan kesehatan meningkat. Perubahan-perubahan dan perbaikan dalam manajemen pelayanan kesehatan khususnya di rumah sakit harus ditingkatkan mengingat banyaknya keluhan masyarakat mengenai pelayanan kesehatan khususnya pelayanan keperawatan.

Untuk memaksimalkan pelayanan kesehatan terhadap masyarakat pemerintah hendaknya menerapkan mekanisme Pola Pengelolaan keuangan (PPK) dan Badan Layanan Umum Daerah Di Rumah Sakit Umum daerah yang penerapannya berdasarkan pasal 60 undang-undang Nomor 1 tahun 2004 tentang perbendaharaan negara dan pasal 7 nomor 44 tahun 2009 tentang RSUD. UndangUndang merupakan patokan ataupun dasar untuk menjalankan sesuatu sistem. Sehingga apabila sistem tersebut dapat dijalankan dengan baik maka apapun bentuk kendalanya akan dapat diselesaikan dengan baik dan cepat pula. RSUD dapat benar-benar menerapkan pola PPK BLUD sesuai dengan amanah undang-undang sehingga tidak ada lagi hambatan dan keluhan baik yang muncul dari pihak RSUD maupun dari masyarakat yang membutuhkan pelayanan kesehatan (Radar Utara 9 Oktober 2012).

Berdasarkan data yang diperoleh dari konsumen RSUD Arga Makmur atau Pasien yang mendapatkan pelayanan kesehatan di RSUD khususnya pelayanan keperawatan, tingkat kepuasan pasien yang mendapatkan pelayanan keperawatan di
Rumah Sakit Umum Daerah (RSUD) belum maksimal dan masih rendah. hal ini ditandai dengan komplain atau keluhan dari masyarakat atau pasien mengenai pelayanan tidak memuaskan atau tidak maksimal kepada pasien dalam banyak hal misalnya Pelayanan keperawatan yang di berikan Dokter atau Perawat terhadap pasien, miskominikasi antara pasien dengan bagian keperawatan, penggunaan Sarana dan Prasarana yang tidak maksimal serta sistem manajemen RSUD yang tidak baik ( Radar Utara 9 Oktober 2012)

Keterangan terhimpun di media Cetak Harian Radar Utara Kabupaten Bengkulu Utara Selasa tanggal 9 Oktober 2012 menyatakan belum maksimalnya pelayanan kesehatan ini dikarenakan banyak hal diantaranya masalah manajemen baik itu kepemimpinan ataupun sistem yang belum berjalan dengan baik. Dari segi Sumber Daya manusia (SDM) misalnya masih kurangnya jumlah dokter spesialis di Rumah Sakit. Kemudian dari segi sarana dan prasarana misalnya terkait belum maksimalnya penggunaan alat-alat kesehatan karena kendala ketidakstabilan arus listrik dan masalah keuangan yang ada di Rumah sakit seperti besarnya tunjangan yang harus dibayarkan kepada dokter spesialis dan masih rendahnya tingkat kesejahteraan perawat di rumah sakit terkait insentif dan jasa, tidak terkecuali sering habisnya stok obat-obatan di Rumah Sakit.

Banyak masyarakat yang mengeluhkan pelayanan kesehatan yang belum maksimal yang diberitakan pada koran harian Radar Utara tertanggal 26 September 2012 Pasien penyakit dalam, saat ditemui di ruang Jamkesmas RSUD Kota Arga Makmur mengungkapkan pihaknya merasakan keuntungan didatangkan dokter spesialis di RSUD tersebut meskipun belum dirasakan secara maksimal mengingat alat-alat kedokteran yang ada belum dapat dimanfaatkan secara maksimal. Kemudian Du ungkapkan lagi 
di koran harian Radar Utara hari selasa tanggal 9 oktober 2012 yang menyatakan "beberapa kalangan (Pasien/Pejabat) yang sudah mulai gerah dan kecewa atas pelayanan RSUD Arga Makmur yang dimulai beberapa tahun belakangan ini tidak ada perubahan justru semakin memburuk. Hal yang cukup masuk akal pasalnya beberapa pejabat tampak berang dengan pelayanan RSUD karena miskomunikasi dalam hal pelayanan Kesehatan, serta lambannya RSUD dalam mempelajari perubahan renumerasi. Selain itu Permasalahan Pasien Jamkesmas dan Jamkesda juga menjadi sorotan terhadap pelayanan kesehatan di RSUD Arga Makmur pada Harian Radar Utara Bengkului Utara tanggal 1 Oktober 2012 seorang pasien tidak mampu tidak diperbolehkan pulang dan harus membayar uang jaminan kepada seorang dokter karena data pasien pada Jamkesmas tidak Lengkap.

Sistem BLUD yang melekat pada RSUD Arga Makmur tampaknya tak menjamin manajemen dan kesejahteraan perawat yang bekerja di Rumah Sakit. Kondisi ini cukup ironis karena pekerjaan mengenai pelayanan ada pada perawat dan dokter. Namun uang jasa serta uang Jamkesmas dan Jamkesda belum dibayarkan oleh pihak Rumah Sakit kepada para perawat (Radar Utara, 2 Oktober 2012). Perawat merupakan orang yang berperan dalam usaha mencapai peningkatan kesehatan dan memberikan memberikan pelayanan kesehatan secara profesional dengan penekanan pada upaya pelayanan kesehatan yang memungkinkan setiap individu mencapai kemampuan hidup sehat dan produktif sehingga harus ada keseimbangan antara pelayanan dan kesejahteraan Perawat.

Oleh karena itu kami tertarik untuk mengetahui sejauh mana pelayanan keperawatan terhadap tingkat kepuasan pasien rawat inap di RSUD Arga Makmur tahun 2012, bertujuan untuk menganalisis hubungan antara kepuasan pasien rawat inap terhadap pelayanan keperawatan di RSUD Arga Makmur Kabupaten Bengkulu Utara tahun 2012.

METODE PENELITIAN

Bagan 1

Kerangka Konsep Penelitia

\section{Variabel Independent Variabel Dependent}

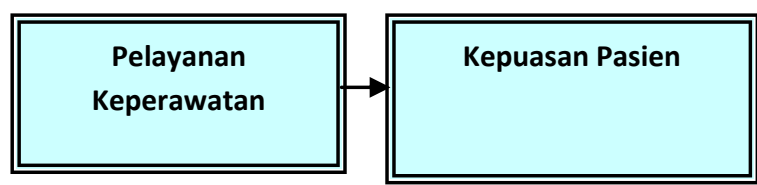

\section{BAHAN DAN PEMBAHASAN}

Jenis penelitian yang digunakan adalah Deskriptif Analitik. Penelitian ini bertujuan untuk membuat gambaran atau deskripsi tentang suatu keadaan secara objektif kemudian dianalisa menggunakan Uji Chi Square. Penelitian ini bersifat Cross Sectional dimana variable resiko dan variable efek di ukur pada saat yang bersamaan (Notoatmodjo, 2005:138). Menurut (Arikunto, 2002:108) populasi adalah keseluruhan objek penelitian. Populasi dalam penelitian ini adalah seluruh pasien yang berada di ruang rawat inap RSUD Arga Makmur Kabupaten Bengkulu Utara tahun 2012.

Sampel adalah sebagian atau wakil dari dari populasi yang akan diteliti (arikunto, 2002:109). Cara penentuan sampel adalah dengan Total Sampling dimana seluruh pasien yang berada di ruang rawat inap pada saat pengumpulan data adalah anggota dari populasi mempunyai kesempatan yang sama untuk menjadi sampel.

Analisa ini bertujuan untuk melihat prosentase masing-masing variabel yang akan diteliti baik variabel bebas (Independen) dalam hal ini adalah pelayanan keperawatan, maupun variabel terikat (Dependen) yaitu kepuasan pasien rawat inap di RSUD Arga Makmur.

Adalah analisa yang dilakukan terhadap dua variabel yang diduga berhubungan atau berkorelasi. (Soekidjo 
Notoatmodjo, 2002: 188). Analisa Bivariat bertujuan untuk mengukur hubungan antara dua variabel dalam hal ini adalah variabel bebas (pelayanan keperawatan) dan variabel terikat (kepuasan pasien rawat inap di RSUD Arga Makmur).

\section{HASIL DAN PEMBAHASAN}

RSUD Arga Makmur berada dalam wilayah Kabupaten Bengkulu Utara. Bengkulu utara adalah salah satu dari 10 kabupaten/kota di Provinsi Bengkulu, dengan ibu kota Arga Makmur, terdiri dari 14 kecamatan, 215 desa dan 5 kelurahan dengan luas wilayah daratan 4.424, 60 $\mathrm{Km}^{2}$. Dari luas wilayah tersebut, wilayah Kabupaten Bengkulu Utara berbatasan langsung dengan Samudera Indonesia maka secara keseluruhan bagian daratan yang berbatsan dengan lautan sepanjang lebih kurang 239,1 Km terdiri dari bagian daratan yang berada di pulau Sumatera sepanjang 115,9 $\mathrm{Km}$ dan wilayah yang berada di pulau Enggano dengan panjang pantai lebih kurang 123,2 Km sehingga sesuai dengan kewenangannya maka Kabupaten Bengkulu Utara memiliki wilayah laut seluas $2.088 \mathrm{Km}^{2}$.

\section{Tabel.1}

\section{Hubungan Analisis Keperawatan terhadap Kepuasan Pasien Rawat Inap RSUD Arga Makmur}

\begin{tabular}{|c|c|c|c|}
\hline Pelayanan & \multicolumn{2}{|c|}{ Kepuasan Pasien } & Total \\
\cline { 2 - 3 } Keperawatan & Tidak Puas & Puas & \\
\hline $\begin{array}{c}\text { Tdk. sesuai } \\
\text { standar }\end{array}$ & 9 & 4 & 13 \\
\hline $\begin{array}{c}\text { Sesuai } \\
\text { standar }\end{array}$ & 0 & 9 & 9 \\
\hline Total & 9 & 13 & 22 \\
\hline
\end{tabular}

Dari table diatas dapat dilihat bahwa pasien yang tidak puas terhadap pelayanan keperawatan dan tidak sesuai standar sebanyak 9 orang dari 9 orang, sedangkan pasien yang puas terhadap pelayanan keperawatan terhadap perawat yang tidak sesuai standar dalam memberikan layanan keperawatan sebanyak 4 orang dari 13 orang. Dan 9 orang dari 13 orang yang puas terhadap pelayanan keperawatan yang sesuai standar yang diberikan oleh perawat

Setelah dianalisis dengan menggunakan bantuan komputerisasi di dapat $X^{2}$ hitung sebesar 10,544 , apabila divabdingkan dengan Xtabel yaitu 3,84 dengan $\alpha=0,05$ dan $\mathrm{P}=0,001$ maka $\mathrm{X}^{2}$ Hitung lebih besar dari Xtabel. Artinya bahwa terdapat hubungan yang signifikan antara Pelayanan keperawatan terhadap kepuasan pasien di ruang rawat inap.

Dari hasil perhitungan selanjutnya diperoleh koefisien kontingensi (C) untuk analisis hubungan pelayanan keperawatan terhadap kepuasan pasien yaitu sebesar 0,569 . Koefisien kontingensi maksimal (Cmkas) berdasarkan table $\mathrm{m}=2$ adalah sebesar 0,707, apabila dibandingkan dengan Chitung maka Cmaks lebih besar dari Chitung yang artinya terdapat hubungan yang nyata antara pelayanan keperawatan terhadap kepuasan pasien di ruang rawat inap RSUD Arga Makmur.

\section{PEMBAHASAN}

Menurut Parasuraman dalam (Tjiptono, 1997) aspek-aspek mutu atau kualitas pelayanan keperawatan mencakup keandalan, ketanggapan, jaminan, empati dan bukti langsung. Dari checklist yang dijalankan pada saat penelitian dapat disimpulkan bahwa hampir seimbang antara pelayanan yang diberikan oleh perawat dan apa yang diterima oleh pasien. Kepuasan pasien menurut Joewono (2003) aspek kepuasan pasien antara lain mencakup ketanggapan,kelengkapan, keterbukaan dan keramahan.

Setelah di skoring dari 21 pertanyaan skor 84-105 dianggap puas dan skor 21-83 dianggap tidak puas. Dari skoring tersebut didapat 9 orang yang puas sesuai standard dan 4 orang yang tidak puas padahal pelayanan keperawatan sudah sesuai standar.

Perlu sangat diperhatikan bahwa standar pelayanan keperawatan memang sangat penting untuk di terapkan oleh para 
perawat di setiap layanan kesehatan khususnya Rumah Sakit. Selain mempengaruhi kepuasan pasien, hal ini juga dapat membuat pencitraan sebuah Rumah Sakit agar tetap dipercaya dalam pemberian pelayanan kesehatan. Hal ini yang membuat masyarakat yakin untuk kembali lagi ke sebuah Rumah Sakit untuk mendapatkan pelayanan kesehatan.

\section{KESIMPULAN DAN SARAN}

Dapat disimpulkan bahwa dari hasil perhitungan chi-square bahwa pasien yang puas terhadap pelayanan keperawatan seimbang dengan pasien yang tidak puas terhadap pelayanan keperawatan yaitu dengan nilai 10, 544. Nilai ini lebih besar dari nilai table yaitu 3,84 yang artinya terdapat hubungan yang signifikan antara pelayanan keperawatan dan kepuasan pasien.

Dapat disimpulkan bahwa dari hasil perhitungan chi-square bahwa pasien yang puas terhadap pelayanan keperawatan seimbang dengan pasien yang tidak puas terhadap pelayanan keperawatan yaitu dengan nilai 10, 544. Nilai ini lebih besar dari nilai table yaitu 3,84 yang artinya terdapat hubungan yang signifikan antara pelayanan keperawatan dan kepuasan pasien.
Masukan untuk bagian keperawatan di RSUD Arga Makmur untuk lebih meningkatkan pelayanan keperawatan yang sesuai dengan standar yang telah ditetapkan. Selanjutnya para perawat harus diberikan sosialisasi mengenai standar pelayanan keperawatan yang digunakan di RSUD Arga Makmur.

\section{DAFTAR PUSTAKA}

Azwar, Azrul. Pelayanan Keperawatan. Rineka Cipta:Jakarta. 1996

Aditama. Kualitas Pelayanan Keperawatan. Esa Mandiri:Jakarta. 2002

Arikunto. Metodologi Penelitian. Elang Jaya:Surabaya. 2002

Depkes RI. Peran Perawat Dalam Meningkatkan Kualitas Kepuasan Pasien. Jakarta 1985

Hastono. Metode Analisis Kesehatan Masyarakat. Gramedia:Jakarta. 2001

Joewono. Standar Keperawatan Umum. Kencana:Jakarta. 2003

Karsinah. Kebijakan Umum Pelayanan Keperawatan. Sudan:Jakarta. 1998

Notoatmodjo, Soekidjo. Metodelogi Penelitian Kesehatan. Rineka Cipta:Jakarta. 2005

Prasuraman. Keefektifan Layanan Keperawtan. Esa Mandiri:Jakarta. 1997

(Radar Utara 9 Oktober 2012).

Soegiarto. Aspek Penilaian Parameter Kepuasan Pasien. Gogo:Bandung. 1999

Sofian. Metodologi Penelitian. Elang Buana:Bandung. 2005

Wiedenback. Pola Asuh Pelayanan Keperawatan. Setiadi:Surabaya. 1989

Zartika, Debi. Skala Pengukuran Kesehatan. Jayakarta:Jakarta. 2004 